\title{
DA EXPERIÊNCIA POLÍTICA CLÁSSICA À ANÁLISE DE CONJUNTURA
}

O número 107 da revista Lua Nova inicia com um dossiê organizado por Patrício Tierno e Eunice Ostrensky sobre a teoria política clássica e alguns aspectos das heranças grega e romana. No artigo inaugural, Patrício Tierno trata justamente das ramificações da Grécia e de Roma na teoria política e aborda as "mediações interpretativas em jogo na disputa pelo sentido de acontecimentos originados na democracia de Atenas do século V a.C. e na república de Roma no decorrer das últimas décadas do século II a.C.” (Tierno, 2019, p. 15) Em seguida, Antonio Hermosa Andújar propõe fazer uma antropologia da democracia a partir das qualidades e dos ideais dos cidadãos atenienses. No artigo seguinte, Eunice Ostrensky aborda o pensamento de Maquiavel a partir de um ângulo ainda pouco explorado: a ambição e o dilema das leis agrárias. Por estarem relacionadas com a propriedade privada, as leis agrárias explicitam os interesses contrários dos nobres e dos plebeus. No quarto artigo, que fecha este dossiê, Thaís Florêncio de Aguiar apresenta a amizade como conceito fundamental da democracia para os gregos antigos. A leitura continua no campo da teoria política com um texto de Jean Castro no qual ele explora a veia trágica de Maquiavel que se apresentava como um pensador trágico. No sexto artigo deste número, Ivo Coser aborda os conceitos de lei, liberdade e diversidade de fins no pluralismo de valores a partir da obra de Isaiah Berlin. A reflexão no campo da teoria política prossegue com um artigo de Antonio Claudio Engelke Menezes Teixeira sobre a fantasia utópica antipolítica e anarquista de Negri e Hardt, que o autor critica. Nos dois últimos artigos da revista, o olhar se volta para o 
Brasil. Primeiro com um texto de Fabio Mascaro Querido no qual a contribuição original de Roberto Schwarz, que propõe pensar o Brasil ao quadrado, é esquadrinhada. Por fim, este número se encerra com um artigo de Jorge Gomes de Souza Chaloub no qual são abordadas as contribuições do bacharelismo na tradição política brasileira para o surgimento de um discurso liberal udenista.

Todos os artigos foram enviados espontaneamente por seus autores e avaliados por pareceristas, a quem muito agradecemos.

Quando do fechamento deste número fomos surpreendidos pela partida inesperada de Reginaldo Carmello Corrêa de Moraes, grande amigo do Cedec e da Lua Nova, na qual publicou dois artigos que constituem uma boa amostra da sua contribuição para a reflexão em ciências sociais. Em "Estado, mercado e outras instituições reguladoras", publicado no número 58 de Lua Nova, Reginaldo questionava a globalização financeira com frequência apresentada como um fenômeno inevitável, irreversível e unívoco, pois, como afirmava, "existe algo mais entre Estado e mercado (ou entre Estado e sociedade civil) do que podem supor as nossas vãs dicotomias" (Moraes, 2003, p. 127).

Já em “Notas sobre o imbróglio do governo Lula, 2005", publicado no número 65 de Lua Nova e redigido no calor da hora dos acontecimentos, Reginaldo se perguntava o que angustiava a todos os analistas naquele momento:

Aonde vamos parar? A crise política, detonada pelas denúncias de corrupção e financiamento ilegal, promete desdobramentos. Não é possível prever a sua extensão, porque, afinal, a política não é física aplicada e os indivíduos e grupos não são pedras, submetidas à lei da queda livre dos corpos e à gravitação universal. São objetos da análise, mas são, também, atores que agem, reagem, calculam e... contornam aquilo que preveem como indesejável. (Moraes, 2005, p. 201) 


\section{Bibliografia}

MORAES, Reginaldo. 2003. Estado, mercado e outras instituições reguladoras. Lua Nova, n. 58, pp. 121-140.

MORAES, Reginaldo. 2005. Notas sobre o imbróglio do governo Lula, 2005. Lua Nova, n. 65, pp. 179-202.

TIERNO, Patrício. 2019. Teoria política clássica - ramificações de Grécia e Roma. Lua Nova, n. 107, 15-29.

\section{Bruno Konder Comparato}

é professor do Departamento de Ciências Sociais da Universidade Federal de São Paulo (Unifesp).

Guarulhos, SP, Brasil. E-mail<bruno.comparato@unifesp.br>

Orcid: 0000-0001-9356-0362

http://dx.doi.org/10.1590/0102-007010/107 